\title{
Ecological Aspect of Legal Provision of Modern Land Reform as a Factor of Sustainable Development
}

\author{
Olena Zaiets ${ }^{1}$, Yuliia Vlasenko ${ }^{2}$, Diana Busuyok ${ }^{3}$, Elina Pozniak ${ }^{4}$
}

\begin{abstract}
The article is devoted to the analysis of the legal support of the Ukrainian land reform from the point of view of its ecological component and realization of the purposes of sustainable development. The ecological aspect of land reform in our state is represented by separate legislative steps of land rehabilitation. In particular, the organizational and legal bases of land melioration have been improved, including the maintenance of field protective forest belts, the legal bases of land division by purpose and territorial planning, etc. The Law on the Circulation of Agricultural Land is aimed at overcoming the moratorium on the alienation of agricultural land. One of its goals is to create conditions for the rational use of land and soil. And this is a prerequisite for their preservation, restoration and improvement, but requires further legal regulation. The paper uses positive foreign experience in land reforms, as well as international and foreign experience in the legal regulation of rational use and protection of land and soil. It is concluded that at the present stage of land reform, the state is trying to restore the efficient use of Ukrainian lands with minimal expenditure of state resources by creating legal, organizational and economic prerequisites, when landowners, land users and local communities, by virtue of their environmental and social legal awareness, legal culture and responsibilities, will be able to restore Ukraine's land potential and achieve sustainable development goals.
\end{abstract}

Key words: land reform; ecological aspect, sustainable development; land melioration; economic incentives; purpose of land.

\section{Introduction}

Land reform in modern Ukrainian society and state is a continuation of the comprehensive reform of land relations, which began in the post-Soviet period with the adoption of the Resolution of the Verkhovna Rada of the USSR of December 18, 1990 "On Land Reform" and will continue until the common goal of reform — restoration of efficient use of land resources of Ukraine — is achieved. The importance of land and other natural resources for Ukrainian society cannot be overestimated. But, unfortunately, almost 30 years of reforming land relations have not brought the desired result. In September 2015, the UN Summit on Sustainable Development approved 17 Sustainable Development Goals for the period until 2030 (United Nations, 2015). These goals are defined taking into account the current understanding of sustainable development as a

\footnotetext{
${ }^{1} \mathrm{PhD}$, Associate Professor, Department of Land and Agrarian Law, Institute of Law, Taras Shevchenko National University of Kyiv.

${ }^{2} \mathrm{PhD}$, Associate Professor, Department of Ecological Law, Institute of Law, Taras Shevchenko National University of Kyiv.

${ }^{3}$ Doctor of Law, Associate Professor, Department of Land and Agrarian Law, Institute of Law, Taras Shevchenko National University of Kyiv.

${ }^{4} \mathrm{PhD}$, Associate Professor, Department of Ecological Law, Institute of Law, Taras Shevchenko National University of Kyiv.
} 
model of economic growth, in which the use of resources is aimed at meeting human needs while preserving environment, so that these development needs are met not only at the present moment but also for future generations.

National objectives and indicators for monitoring the implementation of tasks and targets for Ukraine's achievement of the Sustainable Development Goals for the period until 2030 are reflected in the National Report "Sustainable Development Goals: Ukraine", published by the Cabinet of Ministers of Ukraine on September 15, 2017 (Ministry of Economic Development and Trade of Ukraine, 2017).

The Decree of the President of Ukraine of January 12, 2015 approved the Sustainable Development Strategy "Ukraine - 2020", where one of its four vectors is the very vector of development, which must ensure, in particular, sustainable economic growth in an environmentally friendly way (sustainable nature management), and which provides for carrying out agricultural and land reforms.

To date, a new Presidential Decree of September 30, 2019 "On the Sustainable Development Goals of Ukraine for the period until 2030" has already been adopted, which supports the idea of ensuring the achievement of global sustainable development goals and the results of their adaptation to the peculiarities of Ukraine's development, stated in the National Report.

Thus, in Objective 2 "Overcoming Hunger" of the National Report "Sustainable Development Goals: Ukraine", the achievement is defined taking into account domestic realities, presenting it as an opportunity to solve food problems through the development of competitive agriculture. Thus, among the priority tasks it is necessary to ensure the creation of sustainable food production systems that contribute to the preservation of ecosystems and gradually improve the quality of land and soil, primarily through the use of innovative technologies. Here the role of indicators has been assigned to the share of agricultural land under organic production in the total area of agricultural land, and its increase by $0.7 \%$ by 2030 compared to 2015 has been planned.

Achieving Goal 15 "Protecting and restoring terrestrial ecosystems" is directly related to the main productive resource of agriculture - land. It is planned to restore degraded lands and soils through the use of innovative technologies and, as a result, reduce arable land in 2030 compared to 2015 by $12 \%$ (28,370.7 thousand hectares), which will increase the share of arable land in the total territory of the country to $47 \%$. It is also planned to expand by $2.8 \%$ (1,695.5 thousand hectares) the area of agricultural land of extensive use, such as hayfields and pastures.

Aware of the danger of destruction, contamination and general soil degradation, the UN Stockholm Conference on the Environment in 1972 first drew attention to the need for soil protection. In 1982, the International Food Organization (FAO) adopted the World Soil Charter, which called on the governments of all countries to consider soil as a global heritage of mankind, and in 1983, UNEP approved the Fundamentals of World Soil Policy.

The purpose of this article is to present the authors' vision of the modern content and prospects of legal support for land reform with an emphasis on the environmental aspect of this social phenomenon in the context of sustainable development and international legal trends in soil protection. 


\section{Literature Review}

In the legal literature, it is thoroughly proved that modern land reform is the social relations of procedural nature regulated by law, which mediate the transition of society and the state from old land relations to qualitatively new ones, within which state bodies, citizens and their organizations exercise their rights and obligations on the redistribution of land, reinforcing measures for their protection, lawmaking and improving the system of public administration in the field of use and protection of land resources in order to restore the effective use of lands of Ukraine (Zaiets, 2006, pp. 28-29). Reform is a category of social development (Zaiets, 2006, p. 8), the participation of the state in which is mandatory.

Problems of ecological and legal support of the current stage of land reform in Ukraine are studied in the works of Malysheva N.R., Lisova T.V., Anisimova G.V., Suietnova E.P. (Proceedings of the scientific and legal conference, 2020), Zaiets O.I. (Zaiets, 2006) and others. Abroad, land reform issues were addressed in the works of Ben White, Saturnino M. Borras Jr. and Ruth Hall (White et al., 2014), Tasso Adamopoulos and Diego Restuccia (Adamopoulos and Restuccia, 2020), Elias H. Tuma (Tuma, E.H.), Malcolm Combe, Jayne Glass, Annie Tindley (Combe et al., 2020) and others. We should note that foreign researchers, unlike their Ukrainian colleagues, do not identify an independent environmental direction of land reforms, which can obviously be explained by the relatively separate legal regulation of environmental relations in the field of land protection at both international and national levels.

\section{The content and disproportions of the current stage of land reform in Ukraine.}

The current stage of Ukrainian land reform concerns all the above areas: economic (measures to overcome the moratorium on the alienation of agricultural land, address the fate of collective land, land consolidation, empowerment of independent territorial communities, overcoming raids, etc.), environmental (measures for the protection of melioration lands and field protective forest belts, etc.), institutionalfunctional (measures to improve the maintenance of the state land cadastre, land management, improvement of the territorial planning function, including through the implementation of a comprehensive plan of spatial development of the territorial community, improvement of the procedure for establishing and changing the purpose of land, etc.) and law-making (the Verkhovna Rada of Ukraine has adopted and is considering more than a dozen bills, related to the regulation of land relations) (Ministry of Economic Development, Trade and Agriculture of Ukraine).

But, as correctly noted by H. A. Grigorieva, modern reform has a pronounced agrarian direction (Grigorieva, 2020). And sharing the opinion of this author that between the components of land reform there is an unfortunate imbalance, which may be of strategic importance (Grigorieva, 2020), we will add that this imbalance is not directed in favour of the ecological aspect of land reform. The consequences of such an oversight is the deprivation of the reform of its social content, and this is quite dangerous because it will have its echoes in food security, environmental relations and socio-demographic problems (Grigorieva, 2020). The inconsistency of state policy in the field of reforms in various 
spheres of life indicates a low level of legal culture in society, the lack of clear guidelines and vectors for the development of reform processes, including in the field of land relations.

It is difficult to determine the starting point of the current stage of land reform as it continues to be implemented without separate concepts or programs. We support the opinion of N. R. Malysheva that all important factors were ignored: the state has not developed common conceptual basis for the implementation of the relevant reform in all the years of building an independent state; all "optimization" and "reform" of the relevant area were carried out situationally, unsystematically, often for populist reasons or as a result of lobbying by the most powerful economic players, in the face of confrontation between different political forces, without understanding its purpose and the need to establish a balance of state, group, economic and individual interests (Malysheva, 2020). Therefore, the lack of a specific strategy of reforms in the state, their assessment in terms of environmental friendliness and the lack of legal culture of reforms are obvious, especially in the field of land relations.

The ecological direction of land reform, which, in our opinion, is the intensification of measures directly aimed at improving the quality and quantitative composition of land in Ukraine, is traditionally poorly represented at the present stage, although the Basic Principles (strategy) of state environmental policy of Ukraine for the period until 2030 once again emphasize that the state of land resources of Ukraine is close to critical. At the same time, some steps of ecological improvement of lands, especially agricultural ones, have been taken. Therefore, we can talk about some environmental and legal aspects of the current stage of land reform in our state and society. Land reform in Ukraine has not yet received a full-fledged environmental direction.

It should be noted that foreign experience proves the possibility of effective reform of land legal relations in the direction of sustainable development exactly by creating appropriate organizational and legal principles and clear guarantees from the state through land redistribution, improving the conditions of land ownership and land use, creating a specially authorized body (as is the case with the Scottish Land Commission, for instance), without direct intensification of land protection measures.

Specifically, we are talking about the land reform in Scotland in 2003, which obtained new regulation in connection with the adoption of the Land Reform (Scotland) Act 2016 (Land Reform (Scotland) Act, 2016). A detailed analysis of how Scotland's land is regulated, used and managed has been made in the latest scientific literature (Combe et al., 2020). Of a particular interest here is the Right to buy land to further sustainable development (part 5).

Initially, community groups in Scotland received the preemptive right to buy land in rural areas, postulated in Part 2 of the Land Reform (Scotland) Act of 2003. This right essentially, the right of first refusal - has been later on expanded to urban lands (Community Empowerment (Scotland) Act of 2015). Furthermore, since 2015, community groups enjoy the right to buy lands without them actually being offered for sale by the owner if the land in question does not receive appropriate treatment, being environmentally detrimental, abandoned or neglected (Lovett and Combe, 2019).

Persuading its strategy, already in 2016 Scottish Parliament expanded this right to buy any land in Scotland: fields, woodlands, forests, reservoirs, community centres, churches, 
schools and public houses, should the new owner have scope to use such land for further sustainable development, including salmon fishing and mineral rights. Exception to this right constitutes an ineligible land, for example, land plots under private housing, (Part 5 of the Land Reform (Scotland) Act of 2016) (Cabinet Secretary for Environment, Climate Change and Land Reform, 2020).

Land selection process is regulated by The Right to Buy Land to Further Sustainable Development (Eligible Land, Specified Types of Area and Restrictions on Transfers, Assignations and Dealing) (Scotland) Regulations 2020 (Cabinet Secretary for Environment, Climate Change and Land Reform, 2020). Subject to statutory regulations, a community body can nominate a third party as a purchaser of such eligible for the acquisition land, and the transaction may be forced even without the consensus of the owner. The Right came into force in April 2020 (Scottish Government, 2020).

Let us now briefly compare this Scottish institute of land reform with its Ukrainian counterpart. The Law of Ukraine "On Expropriation of Land Plots and Other Real Estate Objects Located on Private Ownership for Public Needs or for Motives of Public Necessity" provides for and procedurally regulates the right to repurchase land plots and forcibly alienate them. But this institution is not a measure of land reform in Ukraine, it takes place on clearly defined grounds of social necessity, which are not justified as goals of sustainable development.

Only private lands are subject to redemption (forced alienation), while the right to buy land to further sustainable development applies to all forms of ownership (except for Crown lands), but has a number of types of land that are not subject to such purchase altogether. It is important that community bodies must assess any other possible ways to act in the best interests of the community and clearly indicate community benefits from the acquisition, as well as any other possible reasons (Cabinet Secretary for Environment, Climate Change and Land Reform, 2020). The buyout decision is first voted on by the community and then approved by the Scottish Ministers, while in the Ukrainian analogue, decisions are made only by authorized bodies, and territorial communities are not involved. After all, the most important thing with this regard is that our redemption (forced alienation) of lands does not directly pursue the goals of sustainable development and is not substantiated by them, although some grounds are of an ecological nature (as for the objects of nature reserves, for instance).

Described in the scientific literature, the first examples of the implementation of the right to buy land to further sustainable development, in particular, the ancient buildings of the Church of Scotland in Portobello (Edinburgh) (Lovett , 2019), allowed researchers to draw conclusions about the complexity of such measures on the one hand, and on the other - about the success of their implementation in this particular case thanks to a wellorganized campaign of a specially created public body (as required by law) and financial support of the Government. But as the land and real estate became the property of the Portobello community, the question arose about the long-term prospects of using these facilities for sustainable development. The community will have to make a lot of efforts to implement this.

From the standpoint of Ukrainian land reform, this Scottish example of the implementation of the right to buy land to further sustainable development proves that in order to achieve this goal, apart from organizational efforts and financial support by the 
Government (which is provided individually), an appropriate level of legal awareness and environmental-legal culture is required in order not only to get these lands into the ownership of the community, but also to continue their successful use for sustainable development purposes.

\section{Improving the organizational and legal framework for land melioration as a step towards sustainable development}

Let us now discuss the Law of Ukraine of July 10, 2018 "On Amendments to Certain Legislative Acts of Ukraine to Address Collective Land Ownership, Improving Land Use Rules in Agricultural Land, Preventing Raids and Promoting Irrigation in Ukraine", which entered into force on January 1, 2019.

The key task of this Law is to finally resolve the fate of lands that are on the right of collective ownership - a legal title that arose under the Land Code of Ukraine of December 13, 1992, but is not regulated by the current Land Code of Ukraine of October 25, 2001 (hereinafter - LCU). However, in addition, a number of norms in the Law are devoted to improving the organizational principles of land melioration and the legal regime of land plots occupied by protective forest belts. We will discuss these issues in grater details below.

4.1. Land melioration is a complex of hydrotechnical, cultural, chemical, agrotechnical, agroforestry and other melioration measures, carried out to regulate water, heat, air and nutrient regime of soils, preservation and increase of their fertility and formation of ecologically balanced rational structure of lands (Article 1 of the Law of Ukraine "On land reclamation" of January 14, 2000).

The need for this agro-environmental measure to improve the condition of agricultural land is noted in numerous government programs. For example, the Comprehensive Program for the Development of Land Reclamation and Improving the Environmental Condition of Irrigated and Drained Lands for the period until 2010 stated that reclaimed land is, in fact, an insurance fund of the state. The economic, ecological and social situation in the country depends on the efficiency of their use and preservation. As a result of the economic crisis, the efficiency of irrigated and drained lands and their role in food security of the state has significantly decreased: rapid rates of moral and physical aging of reclamation systems and facilities, failure of major melioration funds, significant lack watering of irrigated lands, deterioration of technical condition of melioration network.

According to the analytical report for 2011 of the State Audit Office of Ukraine on the effectiveness of the Comprehensive Program, none of the tasks of the Comprehensive Program during 2007-2009 has been performed, and, therefore, no improvement in the industry has been achieved. Consequently, such lack of actions led to inefficient budget expenditures.

Currently, there is a National Target Program for Water Development and Environmental Rehabilitation of the Dnieper River Basin for the period until 2021 (Law of Ukraine of May 24, 2012), which is funded in accordance with the Resolution of the Cabinet of Ministers of Ukraine of March 29, 2017 № 205 "On Approval of the Procedure for the Use of Funds Provided in the State Budget for the Development and Improvement 
of the Ecological Condition of Irrigated and Drained Systems." Therefore, the Government is taking measures to restore state melioration funds.

A positive step in ensuring sustainable ecologically balanced development of agriculture in Ukraine is the approval by the Order of the Cabinet of Ministers of Ukraine of August 14, 2019 № 688-r of "Strategy of Irrigation and Drainage in Ukraine for the period until 2030", the implementation of which must be achieved by preserving and restoration of soil fertility (Lisova, 2020). This Order also provides for the development of an Action Plan for the implementation of this Strategy. Yet, the Plan has not been approved and put into effect up to date, and, therefore, there is no funding provided for this purpose.

The Law of Ukraine of July 10, 2018 provided for a number of provisions that should help the Government to fulfil its obligations in the field of land melioration:

1) LCU is supplemented by Article 37-1, which creates conditions for the consolidation of individual land plots into agricultural land, which will allow for more efficient use of melioration systems, available in such areas;

2) the list of types of land easements (servitudes) was supplemented by the right to place (move) objects of engineering infrastructure of melioration systems (Article 99 of the Land Code), and in the Law of Ukraine "On Land Melioration" a separate Article 251 has been devoted to this issue;

3) Article 25 of the Law of Ukraine "On Land Melioration" is supplemented by a number of new responsibilities of owners, users, including tenants of meliorated lands, regarding the proper operation of melioration systems;

4) provides for the right of an individual, who has the right to use a significant part of the agricultural land, on which hydrotechnic melioration is carried out, to reimburse the costs of hydrotechnic melioration of land located in such an array, or adjacent land, which is not in its use;

5) in order to ensure proper ecological and melioration state of lands, proper quality of irrigation water and biological needs of crops, and prevent the risk of soil degradation, the Cabinet of Ministers of Ukraine sets standards for environmentally safe irrigation, drainage and management of irrigation or drainage (Article 25 of the Law of Ukraine "On Land Reclamation lands" (currently is only a project).

However, in our opinion, improving the efficiency of land melioration under such legislative changes depends more on the awareness of the importance of proper operation of melioration systems of landowners and land users themselves.

4.2. Implementation of melioration measures not only improves the chemical and physical properties of soils and recuperates land, but also ensures the formation of forest melioration systems, creates appropriate conditions for agricultural plants, forests and other plantations (Lisova, 2020, p. 348). This means that the creation and operation of protective forest belts is a kind of melioration measures (Article 8 of the Law of Ukraine "On Land Reclamation").

The condition of forest belts in Ukraine is critical. Experts of the National Ecological Centre note that in most regions of Ukraine forest belts are in a terrible state, both due to the use of firewood by local residents and due to the undetermined status and lack of professional care (Open Forest, 2020). Ukraine is losing thousands of hectares of 
protective belts that are meant to protect agricultural land from drought and soil erosion. This is evidenced by the results of monitoring the condition of protective plantations, conducted by specialists of the State Service of Ukraine for Geodesy, Cartography and Cadastre (State Geocadastre, 2020).

Until recently, land plots under protective forest belts belonged to forestry lands. The Law of Ukraine of July 10, 2018 amended the LCU and the Forest Code of Ukraine, transferring them to the category of agricultural land. In accordance with paragraph 7 of Article 37-1 of the LCU, land plots under protective forest belts, which limit the mass of agricultural land, are transferred for permanent use to state or municipal specialized enterprises or leased to individuals and legal entities with mandatory inclusion in the land lease agreement of conditions for the maintenance and preservation of such belts, and ensuring that they perform the functions of agroforestry melioration. The rules of maintenance and preservation of field protective forest belts located on agricultural lands are established by the Cabinet of Ministers of Ukraine (Resolution of July 22, 2020, № 650). Funding for such works is provided by the users of these lands.

In conclusion, we would like to note the positive tendency of the legislator to create legal and organizational conditions for the restoration of meliorated lands and land plots under protective forest belts. But this should happen mainly at the expense of landowners and land users themselves, as the law has imposed such an obligation on them.

\section{Formation of the market of agricultural lands and protection of soils.}

Highlighting the problems of the ecological direction of modern land reform, we would like to mention the Law of Ukraine of March 31, 2020 "On Amendments to Certain Legislative Acts of Ukraine on the Conditions of Circulation of Agricultural Land". It does not contain a direct environmental component as it is aimed at overcoming the moratorium on the alienation of certain types of agricultural land. But one of the goals of lifting the moratorium is to create conditions for the rational use of agricultural land, especially soils. And this, in turn, is a prerequisite for their preservation, restoration and improvement.

According to the analysis by the World Food Program (UN Food Program), due to the coronavirus pandemic this year alone, about a quarter of a billion people on the planet could suffer from famine, which, according to program director David Beasley, could lead to famine of "biblical proportions" and cause humanitarian and food disasters. No country can yet fully assess the scale and impact of the economic crisis and the COVID-19 coronavirus pandemic on the country's economy, finances and budget (Ukrinform, 2020).

The global food crisis, which is now increasingly engulfing the planet, poses not a potential but a real threat of the beginning of a protracted phase of permanent local conflicts, and in the long run - global confrontation as well. The dynamics of these conflicts will be determined by the extent to which the countries involved in this confrontation will be able to gain access to important land and water resources (Baliuk et al, 2018).

In the contest of the growing threat of the global environmental and economic crisis, the problem of soil degradation and protection is crucial as food security around the world depends on the condition and quality of soils and water resources. 
According to experts, Ukraine's famous black soils (chernozems) are capable of feeding more than 300 million people provided that the land is used efficiently. However, every year this potential becomes less and less impressive. Ukrainian soils lose their fertile qualities, meaning, the ability to produce Earth's biomass and, consequently, agricultural products and food for the population.

The essence of land reform lays not so much in lifting the moratorium on the sale of agricultural land, as in bringing order to land relations. However, experts fear that speculative buying of agricultural land for resale could create grey market, where the cultivation of land would stop because not every buyer would be engaged in farming, but rather purchase land for resale, waiting for an increase in its prices. Therefore, it is extremely important to address the issue of how may the fertility of soils be preserved and ensured under the new conditions (Rzcheutska, 2020).

The opening of the market for agricultural land in Ukraine cannot leave any citizen indifferent, as this act is associated with both greater opportunities for economic growth and new risks to food and environmental security of the country. Due to the circumstances when Ukraine and the world are on the verge of economic crisis, it is obvious that the issue of land market implementation requires more detailed consideration and attention to today's challenges (Rzcheutska, 2020).

First of all, it is necessary to determine whether the legal regulation of soil protection is sufficiently ensured and whether the measure of responsibility of land users, including "short-term" tenants, for maintaining the quality of soils is effective.

Article 14 of the Constitution of Ukraine states that land is the main national wealth and is under special protection of the state. The Law of Ukraine of June 19, 2003 "On Land Protection" defines the legal, economic and social bases of land protection in order to ensure their rational use, reproduction and increase of soil fertility and other useful properties of land, preservation of ecological functions of soil cover and environmental protection. Thus, Art. 35 of the Law of Ukraine "On Land Protection" in the content of land protection includes the legal obligation of landowners and land users, including tenants, to carry out a number of land protection measures.

The Law of Ukraine of June 19, 2003 "On State Control over Land Use and Protection" defines the legal, economic and social bases for organizing state control over land use and protection and is aimed at ensuring the rational use and reproduction of natural resources and environmental protection. There is a number of regulations detailing the optimal ratio of land, the quality of soils, the maximum allowable pollution etc. Also, the resolution of the Cabinet of Ministers of Ukraine of February 11, 2010 №164 approved the standards of the optimal ratio of crops in crop rotations in different natural and agricultural regions.

At the same time, the mandatory approval of crop rotations for individual farms was abolished in 2015, and state control over crop rotations is almost absent. In our opinion, the control function should belong not only to the central executive bodies, but also to the local self-government bodies on the territory of which the crops are located.

It is clear that the landowner and land user must independently determine a set of measures aimed at increasing the fertility of the soils of their lands. However, any land user can act only within its financial capabilities, and the state must act as a guarantor of compliance with legal requirements for maintaining and increasing soil fertility, the priority 
should lay in the implementation of environmentally sound systems of agricultural production and application of adapted to local and environmental-climatic conditions technologies.

In this context, it is advisable to turn to foreign experience. Thus, in the European Union, a European Soil Bureau conducts constant monitoring of lands, the results of which are recorded in a special database. They have developed a common European soil strategy - a program that obliges member states to conduct land surveys and implement local programs to protect them from degradation. Each member state will decide for itself, which territories and from which land threats to protect, but the standards and reporting will be common. The strategy is currently being approved, so national soil protection mechanisms are still in place (Main Department of the State Geocadastre in the Mykolaiv Region, 2011).

In the UK, the Department of the Environment, Food and Agriculture has numerous support programs for farmers. Their participants undertake to provide full information on the condition of their lands. In the report, in particular, they should inform about the signs of erosion, reduced humus content, and so on. In addition, there is a restriction on harmful to the soil stubble burning for certain species of plants, as well as particular hours and days of the week (Main Department of the State Geocadastre in the Mykolaiv Region, 2011).

In the Czech Republic, landowners pay a land tax, the amount of which depends on the value of the land. $60 \%$ of these funds go to the State Environmental Fund, which then pays, in particular, for soil protection measures (Main Department of the State Geocadastre in the Mykolaiv Region, 2011).

In the United States, there is a special department in the Natural Resources Protection Service, which inspects lands and constantly publishes information about their condition. This agency monitors indicators and regularly issues maps and catalogs that can be used to track the general condition of lands. Although American farmers mostly do not neglect agricultural technologies, there are special programs for the protection of agricultural land and conservation of natural resources (Main Department of the State Geocadastre in the Mykolaiv Region, 2011).

It should be noted that building an effective economic mechanism for restoring soil fertility requires the formation of regulatory framework, as well as institutional changes in land, environmental and tax legislation in the direction of harmonization of domestic institutional norms with European ones. First of all, it is necessary to adopt the Law of Ukraine "On Soil Conservation and Protection of Their Fertility", which would regulate the issue of legal protection of soil, and to amend other regulations. It is also necessary to approve the National Soil Protection Program of Ukraine, to involve specialized scientific institutions in its implementation, to ensure its proper funding. Taking into account the provisions of the Concept of local self-government reform and territorial organization of power in Ukraine, regional programs for soil protection and reproduction of their fertility should be developed and implemented in practice (Korchynska, 2017).

Finally, the environmental direction of Ukrainian land reform needs budget funding. Along with the above, the Resolution of the Cabinet of Ministers of Ukraine of March 9, 2011 № 219 “On Approval of the Procedure for Using Funds Provided in the State Budget for Land Reform Measures" (as last amended on December 4, 2019) and the Resolution of the Cabinet of Ministers Of Ukraine of March 3, 2020 № 169 "On Approval of the 
Procedure for the Use of Funds Provided in the State Budget for Land Inventory and Updating the Cartographic Basis of the State Land Cadastre" are in force at present. Unfortunately, land protection measures are not listed among the objects of budget financing.

Under such legislative conditions, land protection is a completely conscious and voluntary affair of landowners and land users themselves. Therefore, only the proper level of their environmental and legal culture is the key to sustainable use of Ukrainian lands.

\section{The system of land division by purpose and spatial planning.}

The Law of Ukraine of June 17, 2020 "On Amendments to Certain Legislative Acts of Ukraine on Land Use Planning" introduces significant changes in the procedure for determining and establishing the purpose of land plots. In particular, the category of land and the type of purpose of the land slot are determined within the relevant type of functional purpose of the territory, provided by the approved comprehensive plan of spatial development of the territorial community (a new type of planning documentation of simultaneous complex urban and land management) or master plan of the settlement. Decisions to change the category of land and the type of its intended use are made by landowners and, in some cases, land users. Development of a land management project in this case is not required.

Although the given Law will enter into force a year after its publication and provides for the whole range of preparatory measures, it is the first serious step towards the complete abolition of the Soviet system of continuous division of land by purpose.

Such a rigid system of land division by purpose is absent in foreign countries that are not post-Soviet. Instead, the system of territorial planning works successfully, which makes it possible to take into account the individual characteristics of the development of specific areas. Recently, more and more attention is paid to the introduction of various restrictions and registration procedures to ensure rational and environmentally friendly land use (Pravdiuk, 2018, p. 145).

It should be noted that since 2011 (with the adoption of the Law of Ukraine "On Regulation of Urban Development"), Ukraine is also trying to introduce and improve the system of spatial planning, taking into account EU requirements and successful foreign experience. At the same time, the system of land division by purpose remains in place. Compliance with the requirements of these two parallel systems is taken care of by various government agencies, which creates unjustified difficulties for themselves, as well as for landowners and land users. The existing division of land into categories by purpose does not fulfill the task of land protection, does not provide a safe environment and does not take into account the principle of sustainable development (Pravdiuk, 2018, pp. 127-128).

It is noteworthy that in the developed world, there is no clear categorization of land by purpose of use, and even if it does exist, it is not legally binding. Most often, land classifications are used for statistical purposes, for ease of use in the settlement of lease relations or for uniform practice in the field of planning and development of territories (Pravdiuk, 2018, p. 140). For example, the UK has created the National Land Use Database: Land Use and Land Cover Classification, posted on the government website. The aim of the classification is to establish a standardized national nomenclature, which 
would define groups of land use and land cover features in order to assist bodies involved in the routine collection of land use and land cover data Ministry of Housing, Communities \& Local Government, 2006). Also, in the UK, land users are required to provide information on the current type of land use (Pravdiuk, 2018, p. 145).

Interestingly, foreign legislation sometimes uses land classifications specifically for the purpose of a separate regulation. Thus, Article 45 part 5 of the "Right to buy land for further sustainable development" Land Reform (Scotland) Act 2016 provides a separate list of land types for the purposes of this section. "Meaning of "land" (1) In this Part "land" - (a) includes - (i) bridges and other structures built on or over land, (ii) inland waters, (iii) canals, (iv) the foreshore, being the land between the high and low water marks of ordinary spring tides, and (v) salmon fishings in inland waters or mineral rights which are owned separately from the land in respect of which they are exigible, (b) does not include land consisting of any other separate tenement which is owned separately from the land in respect of which it is exigible" (Land Reform (Scotland) Act, 2016, Part 5.45). Here, the obligation of target use is not established.

It should be noted that the legal regulation of land use planning in Ukraine is executed from top to bottom, namely, from the national to the local level. According to the common foreign legislation practice (Ministry of Construction of The Republic of Poland and Ministry of Regional Development of The Czech Republic, 2006; Izdebski, 2007; Wright, 2000), land use planning takes place first at the local level, then at the regional level, and at the last stage - at the national level. The above system of land use planning allows to take into account the features and needs of land use at each level of the organization of the country. Notably, in such cases, local authorities enjoy a high degree of freedom in land use planning.

As a general rule, land use planning activities take place in two stages. At the first stage, the authorized entities develop a general concept of land use planning. At the second stage, it is detailed in the following planning documents. These provisions should be taken into account when improving land use planning under Ukrainian law. The latter occurs first at the national level and only later — at the local level.

As a step towards this matter, the Law of Ukraine of June 17, 2020 provides for the introduction of a new type of planning documentation - a comprehensive plan of spatial development of the territorial community, which will be both urban planning documentation at the local level and land management documentation defining planning organization, functional purpose principles and directions of formation of the uniform system of public service of the population, road network, engineering and transport infrastructure, engineering preparation and improvement, civil protection of the territory and the population against dangerous natural and technogenic processes, protection of lands and other components of the environment, the formation of the ecological network, protection and preservation of cultural heritage and the traditional nature of the environment of settlements, as well as the sequence of implementation of decisions, including phased development of the territory.

\section{Economic incentives for sustainable land use and land self-control.}


Citizens and legal entities have become owners of land relatively recently. Land plots began to be actively included in the economic turnover in the early 90 s of the 20th century.

The legislation assigned to landowners not only the right to extract the useful properties of land but also the obligation to ensure the rational use and protection of land. The Constitution of Ukraine declares that property is binding. Property should not be used to the detriment of man and society. Landowners and land users need to learn to take care of the land and control their actions. The proper condition of lands is a guarantee of their efficient use. Those who own land should be the most interested party in maintaining the proper condition of lands and improving their quality. This can be achieved through the introduction of existing land self-monitoring legislation (Busuiok, 2017) and economic incentives for sustainable land use.

Regarding the current state of legal regulation of economic incentives for sustainable land use, the measures of economic incentives announced in the LCU (Article 205) are ineffective due to lack of adequate funding from the state, bureaucratic complications of procedures for its obtaining (Polishchuk, 2020) and, sometimes, lack of legal mechanism for their implementation. In particular, the measures of economic incentives, which have received legal implementation in the current legislation, include:

1) functioning of the Ukrainian State Fund for Support of Farms, which is a state budgetary institution that performs the functions of implementing state policy on financial support for the formation and development of farms (Law of Ukraine of June 19, 2003 "On Farming");

2) advisory activities, which may be carried out at the expense of state and local budgets (Law of Ukraine of June 17, 2004 "On Agricultural Advisory Activities"). Socially oriented advisory services provided at the expense of the State Budget of Ukraine and local budgets are annually determined by the state target program of agricultural advisory activities within the expenditures of the central executive body implementing state policy in agriculture and local socio-economic development programs.

Thus, in the actual absence of effective economic incentives for sustainable land use, there is a need to find alternative measures. We propose to introduce land self-monitoring by law. Varieties of land self-monitoring can be economic, production or corporate control. It should be conducted by the owners and users of land plots or, at their request, by auditors, in the case of a land audit. The results of self-monitoring should be reported, used for the needs of landowners or land users and submitted to the appropriate authorities. These reports should be used to compile a state land cadastre and provide economic incentives for sustainable land use.

In this case, the legal regulation of economic incentives for sustainable land use should include: first, the systematic determination of qualitative and quantitative characteristics of land; second, comparison of previous and current data on qualitative and quantitative characteristics of the state of lands; third, identification of measures that have led to the improvement or deterioration of qualitative and quantitative characteristics of land; fourth, the adoption, on the basis of established data, by the relevant authorities, decisions on economic incentives, in particular, the reduction or exemption from land tax or, conversely, the occurrence of negative consequences, including prosecution. 
Based on the data of land self-control, fixed in the reports, decisions can be made on the absence of need or, conversely, on the need for selective or continuous state, selfgovernment or public control over the use and protection of land.

With this purpose, a self-monitoring agreement should be concluded between the relevant executive or local authorities and the landowner. Such interaction can be considered as a case of public-private partnership in the field of land use and protection. The provisions on this method of economic incentives for sustainable land use should be enshrined in the LCU, and the provisions on public-private partnerships should be stated in the Law of Ukraine of July 1, 2010 "On Public-Private Partnerships".

But the application of the mechanism of land self-control cannot be based on coercion. Therefore, for its effective implementation it is necessary to increase primarily the level of ecological and legal culture of landowners and land users. At the same time, economic incentives for sustainable land use should not be excluded.

\section{Legal culture and land reform}

It is quite natural that one of the strategic goals of the state agrarian policy of Ukraine is the preservation of the country folk as a carrier of Ukrainian identity, culture and spirituality of the nation (Article 2 of the Law of Ukraine "On Basic Principles of State Agrarian Policy for the period until 2015" of October 18, 2005). Substantiated in the science of agrarian law needs of revival and preservation of the country folk as the owner of the land, the carrier of morality and national culture, are the factors confirming priority of development of an agroindustrial complex and social development of a village in national economy of our state. The spiritual and material culture of the country folk is an extraordinary social value and the object of academic studies through the prism of law and legislation, while its formation is a complex social problem (Kovalenko and Pozniak, 2020).

Encyclopaedic literature notes that culture as an integral concept reflects the qualitative aspect of human activity, its creative nature, motivation and stimulation of social activity, mechanisms of social regulation and self-regulation (Lozov, 2007).

In a number of studies of philosophical, culturological, legal, natural and other areas of knowledge, scientists attach special importance to such types of culture as legal and environmental. Representatives of the theory of law consider legal culture as a system of positive manifestations of legal reality, which concentrates the achievements of legal science and practice. It acts as an internal spiritual side of the legal system and permeates legal consciousness, law, legal relations, law and order, law-making, law enforcement and other legal activities (Bytiak and Yakovyuk, 2007).

Ecological culture, according to representatives of philosophical thought, claims the role of a separate branch of human spirituality, knowledge and practice, which determines the nature and ways of human relations with the biosphere. Acquisition of ecological culture is an essential need to ensure the survival and progress of mankind (Krysachenko and Khilko, 2002).

The interpenetration of legal and ecological cultures in human activities for environmental protection, use and reproduction of natural resources, and environmental security produces development and establishment of ecological and legal culture in the 
minds of people, public policy and information environment. Through the prism of ecological and legal culture, ethics, morality and humanity of ecological and legal norms in relation to nature, man in it and all living things, are manifested.

In a broad sense, environmental and legal culture determines the effectiveness of the legislative process in the development and adoption of environmental and legal norms and rules, as well as environmental management and information activities, law enforcement practices, public involvement in environmentally important decisions and interaction with the public.

Extrapolation of these scientific approaches to the field of land reform suggests that the current legal support of the ecological direction of Ukrainian land reform, which is analysed in detail above, is characterized by a low level of environmental and legal culture of the legislator, executive branch and local government. On the other hand, in our opinion, the success of land reform in Ukraine under such conditions directly depends on the environmental and legal culture of landowners and land users.

\section{Conclusions}

Thus, the analysis of the legal regulation of the current stage of land reform leads to the following conclusions: 1) the successful completion of Ukrainian land reform is fully consistent with the goals of sustainable development; 2) modern land reform in Ukraine, which lasts about 30 years, still does not have a unified conceptual support and, therefore, the environmental direction of land reform does not have proper legal regulation and budget funding; 3) foreign researchers, unlike Ukrainian ones, do not single out an independent ecological direction of land reforms, which might be explained by the relatively separate legal regulation of environmental legal relations in the field of land protection; 4) there is a positive trend in the creation of legal and organizational conditions for the restoration of meliorated lands and land plots under protective forest belts, but mainly at the expense of landowners and land users; 5) the level of legal support for soil protection is inadequate comparing to this level in developed countries; 6) in the latest land legislation of Ukraine, there is a positive trend of overcoming the Soviet institution of division by purpose and the transition to spatial planning; 7) economic incentives for rational land use in Ukraine are virtually absent, so it is proposed to introduce land selfmonitoring as an alternative.

In conclusion, we would like to emphasize once again that the Ukrainian state is trying to restore the qualitative and quantitative composition of Ukrainian lands indirectly, with minimal expenditure of public funds and resources, but by creating legal, organizational and economic preconditions, in which landowners, land users and territorial communities will be able to restore the land potential of Ukraine and achieve the goals of sustainable development by the means of their ecological and social legal awareness, ecological and legal culture and responsibility, and careful attitude to the land.

\section{References}

Adamopoulos, T., Restuccia, D., (2020). Land reform and productivity: a quantitative analysis with micro data. American Economic Journal: Macroeconomics, 12(3): p.p.1-39 https://www.aeaweb.org/articles?id=10.1257/mac.20150222. Accessed 03/12/2020. 
Baliuk, G., Vlasenko, Y., Kovalchuk, T. (2018). Problems of ensuring by the state the realization of the Constitutional right of land ownership by the citizens of Ukraine. Sociology of Law. 3-4 (26-27), p.p. 3-12.

Busuiok, D. (2017). Management and service legal relations in land law of Ukraine: monograph. Kyiv: NikaCenter, p.p.1-256.

Bytiak, Yu. P., Yakovyuk, I.V. (2007). Legal culture in the formation of civil society: Monograph. Kharkiv: Pravo, p. 5.

Cabinet Secretary for Environment, Climate Change and Land Reform (2020). Right to buy land to further sustainable development: information and guidance leaflet for community bodies, landowners and other interested parties. (Part 5 of the Land Reform (Scotland) Act 2016). https://www.gov.scot/publications/right-buy-land-further-sustainable-development-informationguidance-leaflet-community-bodies-landowners-interested-parties/. Accessed 03/12/2020.

Combe, M., Glass, J. and Tindley, A. (2020). Land reform in Scotland: history, law and policy (Scotland's land). Edinburgh University Press, 1st ed., p.p. 1-384.

Grigorieva, H.A. (2020). Imbalance of components of land reform: legal analysis. Actual legal problems of land, agricultural and environmental relations in modern land reform. Proceedings of the scientific and legal conference (Kharkiv, May 22, 2020), p.p. 71-73.

Izdebski, H. (2007). Land use and development: polish regulatory framework and democratic rule of law standards / Izdebski, H., Nelicki, A. and Zachariasz, I., Warsaw: Ernst \& Young, p.p. 1-80.

Korchynska, O. (2017). Sustainable development: Economic issues. Visnyk APSTV (4), p.p. 6-9. https://www.socosvita.kiev.ua/sites/default/files/Visnyk_4_2017-6-9.pdf.

Kovalenko, T.O., Pozniak, E.V. (2020). Legal support for the preservation of the culture of the Ukrainian country folk: the current state and prospects for improvement. Journal of the University of Law. Ukrainian Scientific-Theoretical Journal (1), p.p. 253-259.

Krysachenko, V.S., Khilko, M.I. (2002). Ecology. Culture. Politics: Conceptual foundations of modern development. Kyiv: Knowledge of Ukraine, p.p. 1-218.

Land Reform (Scotland) Act (2016). https://www.legislation.gov.uk/asp/2016/18/contents/enacted. Accessed 03/12/2020.

Lisova, T.V. (2020). Legal support of land restoration: theoretical and practical problems: monograph. Kharkiv: Yurait, p.p. 1-396.

Lovett, J.A., Combe, M.M. (2019). The Parable of Portobello: Lessons and Questions from the First Urban Acquisition Under the Scottish Community Right-to-Buy Regime, 80 Mont. L. Rev. 211, p.p. 210228.

Lozov, V.O. (2007). Morphology of culture: thesaurus. Kharkiv: Pravo, p.p. 1-367.

Main Department of the State Geocadastre in the Mykolaiv Region, (2011). In how many years can Ukraine be left without black soil? http://mykolaivska.land.gov.ua/через-скільки-років-україна-можезали/. Accessed 03/12/2020.

Malysheva, N.R. (2020). Land reform in Ukraine: is there an ecological component in it? Actual legal problems of land, agrarian and ecological relations in the conditions of modern land reform. Proceedings of the scientific and legal conference (Kharkiv, May 22, 2020), p. 197.

Ministry of Construction of The Republic of Poland, Ministry of Regional Development of The Czech Republic, (2006). Spatial development study of the Polish - Czech border region: synthesis of national documents. Warsaw, Wroclaw, Prague, p.p.1-81.

Ministry of Economic Development and Trade of Ukraine, (2017). Sustainable Development Goals. https://mepr.gov.ua/files/docs/Національна\%20_оповідь\%20ЦСР\%20України_липень $\% 202$ 017\%20ukr.pdf. Accessed 03/12/2020.

Ministry of Economic Development, Trade and Agriculture of Ukraine. Land reform in Ukraine. https://zemreforma.gov.ua/. Accessed 03/12/2020.

Ministry of Housing, Communities \& Local Government, (2006). National Land Use Database: Land Use and Land Cover Classification. https://www.gov.uk/government/statistics/national-land-usedatabase-land-use-and-land-cover-classification. Accessed 03/12/2020.

Open Forest, (2020). Legal status of forest belts in Ukraine: questions remain. https://www.openforest.org.ua/135456/. Accessed 03/12/2020. 
Polishchuk, O. (2020). State support for farmers: there are options. But there are nuances. https://www.ukrinform.ua/rubric-economy/3012834-pidtrimka-fermeriv-derzavou-e-varianti-alee-j-nuansi.html. Accessed 31/10/2020.

Pravdiuk, V.M. (2018). Division of lands by target purpose according to the legislation of Ukraine: monograph. Kyiv: Alerta, p.p. 1-204.

Proceedings of the scientific and legal conference (Kharkiv, May 22, 2020). Actual legal problems of land, agrarian and ecological relations in the conditions of modern land reform, p. 351.

Rzcheutska, L. (2020). Land reform: how the land market in Ukraine will work now. https://www.dw.com/uk/земельна-реформа-як-діятиме-тепер-ринок-землі-в-україні/a52971700. Accessed 03/12/2020.

Scottish Government, (2020). Right to buy land to further sustainable development (part 5). https://www.gov.scot/policies/land-reform/right-to-buy-land-to-further-sustainabledevelopment/. Accessed 03/12/2020.

State Geocadastre, (2020). https://land.gov.ua/. Accessed 03/12/2020.

Tuma, E.H., Land reform: agricultural economics. https://www.britannica.com/topic/land-reform. Accessed $03 / 12 / 2020$.

Ukrinform, (2020). The famine over the COVID-19 pandemic could affect a quarter of a billion people - the UN. https://www.ukrinform.ua/rubric-world/3024059-golod-cerez-pandemiu-covid19-mozezacepiti-cvert-milarda-ludej-oon.html. Accessed 03/12/2020.

United Nations, (2015). Transforming our world: The 2030 Agenda for sustainable Development. https://sustainabledevelopment.un.org/post2015/transformingourworld. Accessed 03/12/2020.

White, B., Borras Jr, S.M. and Hall, R. (2014). Land reform. // in B. Currie-Alder, R. Kanbur, D. Malone and R.Medhora eds. Development: Ideas, Experience and Prospects. Oxford: Oxford University Press, Ch. 28. https://www.researchgate.net/publication/299932373_Land_Reform. Accessed $03 / 12 / 2020$.

Wright, R. R. (2000). Land use in a nutshell / Wright, R.R., Gitelman, M., St. Paul, Minn: West Group, p.53.

Zaiets, O.I. (2006). Legal aspects of land reform in Ukraine. Monograph. Kyiv: VPTs "Kyiv University", p.p. $1-185$. 